\title{
Foliar Application of Zinc and Iron as Influenced on Flowering and Quality Parameters of Tuberose
}

\author{
Madhuri Tayade, Shalini Badge* and Bhavisha Nikam \\ Horticulture Section, College of Agriculture, Nagpur-440001, India \\ *Corresponding author
}

\section{Keywords \\ Tuberose, \\ Flowering, Spike, quality, Foliar application}

\section{Article Info}

Accepted: 16 December 2017 Available Online: 10 January 2018

\section{A B S T R A C T}

An experiment was carried out to study the effect of foliar application of zinc and iron on flowering and quality of tuberose during the year 2016-2017 at Horticulture Section, College of Agriculture, Nagpur. The experiment was laid out with sixteen treatment combinations with spraying of $\mathrm{ZnSO}_{4}(0,0.2,0.4$ and $0.6 \%)$ and $\mathrm{FeSO}_{4}(0,0.2,0.4$ and $0.6 \%$ ) at 30 and 45 days after planting. Results revealed that among zinc treatments, $0.4 \%$ $\mathrm{ZnSO}_{4}$ recorded significantly minimum days to initiation of first spike (95.38 days), days to opening of first pair of floret (13.60 days), days to $50 \%$ flowering (106.32 days) and days to first harvesting (104.45 days) when compared to the control. Foliar spray of $0.4 \%$ $\mathrm{ZnSO}_{4}$ increased the quality parameters like Length of spike $(81.49 \mathrm{~cm})$, diameter of spike $(0.95 \mathrm{~cm})$, length of rachis $(22.22 \mathrm{~cm})$, length of floret $(4.49 \mathrm{~cm})$, diameter of floret $(3.43 \mathrm{~cm})$ and vase life $(8.67$ days). Among iron treatments, regarding the flowering attributes like early initiation of spike (94.28 days), days to opening of first floret(13.98 days), days to $50 \%$ flowering(106.08 days) and days to first harvesting(103.84 days) were recorded with treatment $0.4 \% \mathrm{FeSO}_{4}$ when compared to the control. Foliar spray of $0.4 \%$ $\mathrm{FeSO}_{4}$ increased the quality parameters like length of spike $(81.56 \mathrm{~cm})$, diameter of spike $(0.96 \mathrm{~cm})$, length of rachis $(23.00 \mathrm{~cm})$, length of floret $(4.48 \mathrm{~cm})$, diameter of floret $(3.45$ $\mathrm{cm}$,) and vase life (9.08 days). Among all the treatments $0.4 \% \mathrm{ZnSO}_{4}$ and $0.4 \% \mathrm{FeSO}_{4}$ sprayed at 30 and 45 days after planting recorded maximum valves for all the parameters.

\section{Introduction}

Tuberose (Polyanthus tuberosa.) is an important and most popular bulbous cut flower grown everywhere in the world. It has innumerable cultivars with sweet fragrance. This flower bears an economic and aesthetic value for its beauty and elegance. The long flower spikes are excellent as cut flower for ornamentation when arranged in vases and single types tuberose loose flowers are used for extraction of essential oil. It has great economic value for cut flower trade and much valued by the aesthetic world for beauty and loving people because its prettiness, sweet fragrance and unparallel elegance (Sadhu and Bose, 1973). Now, it has been trading in domestic and international markets having great demand. Successful production of good quality tuberoses flowers, micronutrients plays a vital role for production of quality flowers, increase the yield by involving in oxidation 
reduction process, photosynthesis and energy transfer. Foliar application of micronutrient was increased physiological activity and productive process in tuberose (Subba Redddy, 2014). Micronutrients especially zinc play vital role in growth and flower quality of gladiolus (Halder et al., 2007). It required in small amount, $\mathrm{Zn}$ is essential for carbon dioxide evolution and utilization of carbohydrate and phosphorus metabolism and synthesis of RNA (Jyoti Sharma et al., 2013). Plant needs iron to produce chlorophyll and to activate several enzymes including those involved in the oxidation/ reduction processes of photosynthesis and respiration. Various experiments have been conducted earlier on foliar spray of micro-nutrients in different flower crops (e.g. in rose, Younis et al., 2013 and in tuberose, Ganesh and Soorianathasundaram, 2015) shown significant response to improve growth flowering and quality. Thus, present experiment was conducted to study the effect of zinc and iron on flowering and quality of tuberose by foliar application.

\section{Materials and Methods}

Field experiment was carried out at Floriculture Unit, Horticulture Section, College of Agriculture, Nagpur during the year 2016-2017. The experiment was laid out in Factorial Randomized Block Design with Factorial Concept (FRBD) with sixteen treatments combinations viz. $\mathrm{T}_{1}-\mathrm{Z}_{0} \mathrm{~F}_{0}, \mathrm{~T}_{2^{-}}$ $\mathrm{Z}_{0} \mathrm{~F}_{1}, \mathrm{~T}_{3}-\mathrm{Z}_{0} \mathrm{~F}_{2}, \mathrm{~T}_{4}-\mathrm{Z}_{0} \mathrm{~F}_{3}, \mathrm{~T}_{5^{-}} \mathrm{Z}_{1} \mathrm{~F}_{0}, \mathrm{~T}_{6}-\mathrm{Z}_{1} \mathrm{~F}_{1}$, $\mathrm{T}_{7^{-}} \mathrm{Z}_{1} \mathrm{~F}_{2}, \mathrm{~T}_{8^{-}} \mathrm{Z}_{1} \mathrm{~F}_{3}, \mathrm{~T}_{9^{-}} \mathrm{Z}_{2} \mathrm{~F}_{0}, \mathrm{~T}_{10^{-}} \mathrm{Z}_{2} \mathrm{~F}_{1}, \mathrm{~T}_{11^{-}}$ $Z_{2} F_{2}, T_{12^{-}} Z_{3} F_{3}, T_{13^{-}} Z_{3} F_{0}, T_{14^{-}} Z_{3} F_{1}, T_{15^{-}}$ $Z_{3} F_{2}, \quad T_{16^{-}} Z_{3} F_{3}$ involving two levels of micronutrients $\left(\mathrm{ZnSO}_{4} 0.2,0.4\right.$ and $0.6 \%$ and $\mathrm{FeSO}_{4}$ 0.2, 0.4 and $0.6 \%$ ) along with control. The treatments were replicated thrice. Bulbs of tuberose were planted on flat bed. The micronutrients were applied two times at 30 and 45 days after planting through foliar spray. Five uniform plants were randomly selected and tagged from the net plot area in each treatment and replication for the purpose of recording the observations. Data regarding flowering parameters as days to initiation of first spike, days to opening of first floret, days to $50 \%$ flowering and days to first harvesting counted from planting in days, length of spike and length of rachis were measured by meter scale, diameter of spike, floret diameter and length of florets were measured by digital Vernier caliper and at the end vase life of flower was counted in days.

\section{Statistical analysis}

The experimental data pertaining to all the characters studied were subjected to statistical analysis of variance technique as described by Gomez and Gomez (1984). The method of analysis of variance for factorial randomized block design (FRBD) was used. The test of significance among treatments was worked out by ' $F$ ' test. The critical difference at five per cent level of probability was worked out wherever the treatment effect were significant to compare mean of two treatments.

\section{Results and Discussion}

A perusal of data from table 1 regarding flowering parameters like days to initiation of spike, days to opening of first floret, days to $50 \%$ flowering and days to first harvesting, length of spike, length of rachis, diameter of spike, floret diameter, length of florets and vase life of flower influenced significantly by zinc and iron.

\section{Effect of zinc on flowering and quality parameters}

It is evident from the data (Table 1) revealed that application of $\mathrm{ZnSO}_{4}$ at different concentration $(0,0.2,0.4$ and $0.6 \%)$ show better results on flowering and quality parameter in tuberose. 
Table.1 Effect of zinc and iron on flowering and quality parameters of tuberose

\begin{tabular}{|c|c|c|c|c|c|c|c|c|c|c|}
\hline Treatment & $\begin{array}{l}\text { Days to } \\
\text { initiation } \\
\text { of spike } \\
\text { (days) }\end{array}$ & $\begin{array}{l}\text { Days to } \\
\text { opening } \\
\text { of first } \\
\text { floret } \\
\text { (days) }\end{array}$ & $\begin{array}{l}\text { Days to } \\
50 \% \\
\text { flowering } \\
\text { (days) }\end{array}$ & $\begin{array}{l}\text { Days to } \\
\text { first } \\
\text { harvesting } \\
\text { (days) }\end{array}$ & $\begin{array}{l}\text { Length } \\
\text { of spike } \\
(\mathrm{cm})\end{array}$ & $\begin{array}{l}\text { Diameter } \\
\text { of spike } \\
\text { (cm) }\end{array}$ & $\begin{array}{l}\text { Length } \\
\text { of } \\
\text { rachis } \\
(\mathrm{cm})\end{array}$ & $\begin{array}{l}\text { Length } \\
\text { of floret } \\
(\mathrm{cm})\end{array}$ & $\begin{array}{l}\text { Diameter } \\
\text { of floret } \\
(\mathrm{cm})\end{array}$ & $\begin{array}{l}\text { Vase } \\
\text { life } \\
\text { (days) }\end{array}$ \\
\hline \multicolumn{11}{|c|}{ Factor A : Z - Zinc } \\
\hline $\mathrm{Z}_{2}$ - Zinc $0.4 \%$ & 95.58 & 13.60 & 106.32 & 104.45 & 81.49 & 0.95 & 22.22 & 4.49 & 3.43 & 8.67 \\
\hline $\mathrm{Z}_{3}$ - Zinc $0.6 \%$ & 98.85 & 14.35 & 113.93 & 111.94 & 78.86 & 0.88 & 20.08 & 4.01 & 3.19 & 8.17 \\
\hline $\mathrm{SE}(\mathrm{m}) \pm$ & 1.24 & 0.36 & 3.08 & 3.09 & 1.48 & 0.01 & 0.74 & 0.13 & 0.09 & 0.21 \\
\hline \multicolumn{11}{|c|}{ Factor B : F- Iron } \\
\hline $\mathrm{F}_{1}$ - Iron $0.2 \%$ & 101.82 & 15.02 & 116.48 & 115.65 & 77.29 & 0.84 & 19.45 & 3.67 & 3.10 & 7.66 \\
\hline $\mathrm{F}_{2}$ - Iron $0.4 \%$ & 94.28 & 13.98 & 106.08 & 103.84 & 81.56 & 0.96 & 23.00 & 4.48 & 3.45 & 9.08 \\
\hline $\mathrm{F}_{3}-$ Iron $0.6 \%$ & 99.12 & 14.45 & 113.98 & 112.05 & 79.82 & 0.87 & 19.52 & 3.89 & 3.16 & 8.41 \\
\hline $\mathrm{SE}(\mathrm{m}) \pm$ & 1.24 & 0.36 & 3.08 & 3.09 & 1.48 & 0.01 & 0.74 & 0.13 & 0.09 & 0.21 \\
\hline CD at $5 \%$ & 3.58 & 1.05 & 8.90 & 9.25 & 4.27 & 0.03 & 2.15 & 0.39 & 0.26 & 0.62 \\
\hline \multicolumn{11}{|c|}{ Interaction effect A x B } \\
\hline $\mathrm{SE}(\mathrm{m}) \pm$ & 4.33 & 0.72 & 6.17 & 6.61 & 2.96 & 0.03 & 1.49 & 0.27 & 0.18 & 0.43 \\
\hline CD at $5 \%$ & - & - & - & - & - & - & - & - & - & - \\
\hline
\end{tabular}


The improvement of flowering attributes were observed by foliar application of $0.4 \%$ $\mathrm{ZnSO}_{4}\left(\mathrm{Z}_{2}\right)$ recorded minimum days taken to initiation of first spike (95.58 days), opening of first floret (13.60 days), 50 per cent flowering (13.60 days) and first harvesting of tuberose (104.45 days). Foliar application of $\mathrm{ZnSO}_{4}$ minimized the days to flower bud initiation and opening of flower bud in gerbera (Khosa et al., 2011). Flowering quality parameters like flower spike length $(81.49 \mathrm{~cm})$, rachis length $(22.22 \mathrm{~cm})$ was found significantly maximum in $0.4 \% \mathrm{ZnSO}_{4}$ $\left(\mathrm{Z}_{2}\right)$. The increase in spike length with zinc might be due to its role in synthesis of IAA that enhanced cell division, cell elongation and plant growth there by more photo synthesis and increased spike length.

Similar results were reported by Katiyar et al., (2012) observed that foliar spray of zinc increased approximately $22-40 \%$ spike length. Subba Redddy et al., (2014) reported that, length of rachis and diameters of spike were recorded maximum with the foliar application of $\mathrm{ZnSO}_{4}$. Diameter of spike $(0.95 \mathrm{~cm})$, length floret $(4.49 \mathrm{~cm})$, diameter of floret $(3.43 \mathrm{~cm})$ and vase life (8.67 days) were found significantly maximum in $0.4 \% \mathrm{ZnSO}_{4}\left(\mathrm{Z}_{2}\right)$. Patle et al., (2014) also showed that micronutrient application is key factor which play a dominant role in successful production of best quality cut roses and increased vase life of flower. Chopde et al., (2016) reported that, vase life was recorded maximum with the foliar application of $0.4 \% \quad \mathrm{ZnSO}_{4}$ in gladiolus.

\section{Effect of iron on flowering and quality parameters}

Application of $\mathrm{FeSO}_{4}$ has remarkable effect on the flowering and quality parameters in tuberose. It is evident from the data revealed that minimum days taken to initiation of first spike (94.28 days) and days to opening of first pair of floret (13.98 days), days for 50 per cent flowering (106.08 days) and days of first harvesting of spike (103.84 days) was recorded in foliar application of $0.4 \% \mathrm{FeSO}_{4}$ $\left(\mathrm{F}_{2}\right)$. Flowering parameters like flower spike length $(81.56 \mathrm{~cm})$, diameter of spike $(0.96$ $\mathrm{cm})$, length of rachis $(23.00 \mathrm{~cm})$, length of floret $(4.48 \mathrm{~cm})$, diameter of florets $(3.45 \mathrm{~cm})$ and vase life flower ( 9.08 days) was recorded significantly maximum in plants treated with $0.4 \% \mathrm{FeSO}_{4}\left(\mathrm{~F}_{2}\right)$. Bhattacharjee, (1993) in rose reported that micronutrient plays an important role involving in photosynthesis; break down of IAA, auxin and protein synthesis. Floret length was maximum due to the raise in the length of pollen tubes, cell division, growth, development and process of respiration in plants (Khosa et al., 2011) in gerbera. The data revealed that significantly maximum number of vase life of cut flower (9.08 days) was found in same treatment i.e. $0.4 \% \mathrm{FeSO}_{4}\left(\mathrm{~F}_{2}\right)$. Vase life was considerably maximum in proper application of micronutrients supported the flowers in the vase for the extended vase life in orchid (Ganga et al., 2009).

\section{Interaction effect of $\mathbf{Z} \times \mathbf{F}$}

The data showed that interaction effect of zinc and iron was found non-significant different flowering parameters like flowering parameters like days to initiation of spike, days to opening of first floret, days to $50 \%$ flowering and days to first harvesting was found non-significant. The data pertaining to length of spike, length of rachis, diameter of spike, floret diameter, length of florets and vase life of flower was found non-significant with respect to interaction effect of zinc and iron.

\section{Acknowledgement}

The author is grateful to Horticulture Scetion, College of Agriculture, Nagpur-440001 
(M.S.) India for providing the logistic support facilities to carry out this study.

\section{References}

Bhattacharjee, S. K. 1993. Response of micronutrients spray on growth and flowering of rose cv. Raktagandha. Indian Rose Annual. 11: 108-113.

Chopde, N., Nehare, N., Bhande, M. H. and Lokhande, S. 2016. Growth, yield and quality of gladiolus as influenced by micronutrients. J. Soil and Crops. 26 (1): 131-133.

Ganesh, S. and Soorianathasundaram, K. 2015. Reflectance of change in physiology due to growth regulator and micronutrient on yield of tuberose cv. Prajwal. Res. Environ. Life Sci. 8(1):97100.

Ganga, M., Padmdevi, K., Jegadeeswari, V. and Jawaharlal, M. 2009. Performance of Dendrobium cv. Sonia 17 as influenced by micronutrients. $J$. Ornamental Hort. 12(1): 39-43.

Gomez, K. A. and Gomez, A. A. 1984. Statistical procedure for Agriculture research, II Edition Singapore, A Willey I International Publication.

Halder, N. K., Ahmed, R., Sharifuzzaman, S. M., Anzu-Man-Ara Bagam, K. and Siddiky, M. A. 2007. Effect of boron and zinc fertilization on corm and cormel production of gladiolus in Grey Terrace soils of Bangladesh. Int. J. Sustain. Crop Prod. 2(5): 85-89.

Jyoti Sharma, A. K., Gupta, Chandan Kumar and Gautam, R. K. S. 2013. Influence of zinc, calcium and boron on vegetative and flowering parameters of gladiolus cv. Aldebran. The Bioscan. 8(4): 11531158.

Katiyar, P., Chaturvedi, O. P. and Katiyar, D. 2012. Effect of foliar spray of zinc, calcium and boron on spike production of gladiolus cv. Eurovision. Hortflora research spectrum. 11(4): 334-338.

Khosa, S. S., Younis, A., Rayit, A., Yasmeen, S. and Riaz, A. 2011. Effect of foliar application of macro and micronutrients on growth and flowering of Gerbera jamesonii L. J. Agric. and Enviro. Sci. 11(5):736-757.

Patel, Henaxi, Bhatt, Dipal Patel, G. D, Chawla1, S. L. and Gurjar, Tulsi. 2016. Effect of foliar application of micronutrients on Growth and flowering of rose cv. Top secret under Polyhouse condition. The Bioscan. 11(1): 603-606

Sadhu, M. K. and Bose, T. K. 1973. Tuberose for most artistic garlands. Indian Hort.18: 17-21.

Subba Reddy, G. V., Nageswara Rao, M. B. and Chandhra Sekhar, R. 2014. Studies on the effect of foliar application of zinc on vegetative growth, flowering, corm and cormel production in gladiolus $\mathrm{cv}$. White prosperity. The Bioscan, VI (Special issue): 35-39

Younis, A., Riaz, A., Sajid, M., Mushtaq, N., Ahsan, M., Hameed, M., Tariq, U. and Nadeem, M. 2013. Foliar application of macro and micronutrients on the yield and quality of Rosa hybrida cvs. Cardinal and Whisky Mac. African J. Biotechnology. 12(7): 702-703.

\section{How to cite this article:}

Madhuri Tayade, Shalini Badge and Bhavisha Nikam. 2018. Foliar Application of Zinc and Iron as Influenced on Flowering and Quality Parameters of Tuberose. Int.J.Curr.Microbiol.App.Sci. 7(01): 2239-2243. doi: https://doi.org/10.20546/ijcmas.2018.701.270 